\title{
Effects of slaughter age and gender on carcass characteristics of Turkish indigeneous Hair goat kids reared under an extensive production system
}

\author{
H. Deger Oral Toplu', Ergun Omer Goksoy² and Ahmet Nazligul' \\ 'Department of Animal Breeding and Husbandry, ${ }^{2}$ Department of Food Hygiene and Technology,Faculty of Veterinary \\ Medicine, Adnan Menderes University, Isikli, Aydin, Turkey
}

\begin{abstract}
This study was conducted to investigate effects of slaughter age and gender on carcass characteristics of indigenous Hair goat kids reared under an extensive production system. A total of 60 Hair goat kids (30 females and 30 males) slaughtered at 3, 6, 9 and 12 months of age was used as the material of this study. In the study, the cold carcass weights of kids at 3-12 months of age were between 6.15 and $10.83 \mathrm{~kg}$. The cold dressing percentage was determined as $47.04-52.65 \%$. The effect of slaughter age on these traits was statistically significant $(P<0.001)$. The cold carcass weight and the cold dressing percentage increased with the slaughter age. The effect of kid gender on the cold carcass weight was statistically significant $(P<0.001)$. The mean value of this trait in males was higher than the females. The percentages of omental-mesenteric fat $(P<0.001)$ and kidney-knob and channel fat $(P<0.01)$ significantly increased with slaughter age. Subcutan, intermuscular, total fat and muscle/ bone percentages of the left half carcass significantly increased with slaughter age $(P<0.01)$. However, bone $(P<0.05)$ and muscle/total fat $(P<0.01)$ percentages significantly decreased with slaughter age. The female kids had significantly higher values than males in terms of omental-mesenteric fat, kidney-knob and channel fat, subcutaneous, intermuscular and total carcass fat percentages $(P<0.001)$. In conclusion, it is recommended that Hair goat kids should be slaughtered at 9 months of age under extensive management system to result in more edible meat production.
\end{abstract}

Keywords: goat, carcass characteristics, slaughter age

Archiv Tierzucht $56(2013)$ 8, 75-88

doi: $10.7482 / 0003-9438-56-008$

Corresponding author:

H. Deger Oral Toplu; email: doral@adu.edu.tr

Department of Animal Breeding and Husbandry, Faculty of Veterinary Medicine, Adnan Menderes University, 09016, Isikli, Aydin, Turkey

(C) 2013 by the authors; licensee Leibniz Institute for Farm Animal Biology (FBN), Dummerstorf, Germany. This is an Open Access article distributed under the terms and conditions of the Creative Commons Attribution 3.0 License (http://creativecommons.org/licenses/by/3.0/).
Received: 27 December 2011

Online: 22 February 2013 Accepted: 4 July 2012 


\section{Introduction}

Goats play a crucial role in the rural economy of Turkey, and the goat population is estimated at 5.1 million heads (Anonymous 2009). The goat breeding in Turkey is based mainly on extensive system carried out by smallholder farmers living in poor agricultural fields. In this system, kids are usually weaned at 2-3 months of age. Kids are allowed to graze with their mother during the day until weaning. After weaning, kids are raised on pasture separately from their mothers. In Turkey, almost $97 \%$ of the goat population consists of indigenous Hair goats, which are mainly located in the mountain areas of the Mediterranean and Aegean regions, although widely distributed throughout Turkey. Hair goats are generally reared under extensive system, with grazing on natural pasture of leaves and branches in the scrub fields with little or no feed supplementation. Hair goats, enduring against disease and harsh environmental conditions, have adapted climatic and environmental conditions of Turkey (Yalcin 1990). In Aegean region, kids are slaughtered after immediately weaning (2-3 months of age) or they are slaughtered at 6-7 months of age or at the age of 12 months, $22-24 \mathrm{~kg}$ live weight in traditional extensive production system, as in the other regions of Turkey (Gursoy et al. 2011).

Goat meat is important protein and income source for people living in rural areas and meat obtained from indigenous kids is preferred by the public in these regions of Turkey. (Yalcin 1990, Guney 2006). The origin of the animals, carcass characteristics and meat quality are important criteria for customer when it comes to making purchasing decisions (Bonvillani et al. 2010). With the desire for leaner meat by consumers, goat meat is attractive compared with other types of red meat (Potchoiba et al. 1990). Compared with sheep, goats deposit more internal and less subcutaneous, intermuscular and intramuscular fat (Colomer-Rocher et al. 1992).

Several studies have been carried out to characterize carcass traits of Hair goat kids and their crossbreeds with milking breeds under intensive or semi-intensive systems (Koyuncu et al. 2007, Yilmaz et al. 2010). However, there is limited information related to carcass characteristics of indigenous Hair goat kids at different slaughter ages under traditional extensive production system.

The aim of this study was to investigate the effects of slaughter age and gender on carcass characteristics of Turkish indigenous Hair goat kids under an extensive production system.

\section{Material and methods}

The research protocol of the present study was approved by The Ethic Committee of Adnan Menderes University, Veterinary Faculty (Approval number: 2007/026).

\section{Animals, slaughter procedure and carcass analysis}

This study was conducted at a private farm in Aydin province of Aegean Region in Turkey in 2008. A total of 60 Hair kids (30 females, 30 males), which were born from Hair goats reared under extensive conditions, were used as the material of this study. The experimental animals were obtained from same farm. Kidding season was January and February in the farm. All 
kids chosen for the study, homogenous for weight and clinically health, were born as single from dams of the same age in the first week of January. The kids were weaned at 3 months of age and then they were fed on natural pasture (grassland between maquis vegetation) without being supplemented with any extra feed. The kids were randomly allocated to one of the four groups according to slaughter age at weaning. There were no any differences among groups in terms of weaning age, farm and feeding regime. The kids in one of the groups were slaughtered at 3 months of age (slaughtered at $14-16 \mathrm{~kg}$ ), after immediately weaning and the others were slaughtered at 6 (slaughtered at 19-21 kg), 9 (slaughtered at $21-23 \mathrm{~kg}$ ) and 12 (23$25 \mathrm{~kg}$ ) months of age using standard commercial procedures in municipality slaughterhouse. Sixteen kids ( 8 males, 8 females) were used for each 3, 6 and 9 months of age groups whereas twelve kids ( 6 males, 6 females) were used to be slaughtered at 12 months of age. Slaughter live weight was recorded after $12 \mathrm{~h}$ fasting with free access to water. The carcass was comprised of the body after the removal of head, skin, feet, testicles and viscera. The carcass included the kidneys, kidney-knob and channel fat. Hot carcasses were weighed and then the weight of head, skin, feet, testicles and visceral organs (heart, liver, spleen, lungs and trachea) were recorded. In order to estimate the empty body weight, full and empty gastro-intestinal tract was weighed and recorded. Empty body weight was estimated subtracting the weight of gastro-intestinal tract content from the pre-slaughter live weight. After the carcasses were chilled at $4^{\circ} \mathrm{C}$ for $24 \mathrm{~h}$, cold carcass weights were recorded. Hot and cold dressing percentages were calculated based on empty body weight. Some carcass measurements and conformation indicators such as carcass width (widest carcass measurement at the ribs), buttock width (widest buttock measurement in a horizontal plane on the hanging carcass), internal carcass length (length from cranial edge of the symphysis pelvis to the cranial edge of the first rib), hind limb length (length from perineum to the distal edge of the tarsus), thorax perimeter (maximum perimeter at widest carcass measurement at ribs), buttock perimeter (maximum perimeter at widest buttock measurements in a horizontal plane on the hanging carcass), thorax depth (maximum distance between the sternum and the back of the carcass at the sixth thoracic vertebrae), carcass compactness index (cold carcass weight/internal carcass weight) and hind limb compactness index (hind leg weight/hind limb length) were taken as described by Santos et al. (2007), Fisher \& de Boer (1994). Cold carcasses were split down the dorsal midline. Weights of left and right halves were recorded. After the tail, kidney, kidneyknob and channel fat in the carcass left side were removed and weighed, left sides were jointed into five primal cuts (neck, shoulder, flank, ribs and long leg) as described by ColomerRocher et al. (1987). The cuts were weighed and expressed as a percentage of the weight of the left half of carcass. The results were expressed as percentage of side weight. After weighing, each cut was separated into dissectible muscle, bone, fat (subcutaneous and intermuscular fat was weighed separately) and remaining tissues (major blood vessels, ligaments, tendons and fascias). The percentages of muscle, bone, subcutaneous and intermuscular fat of each left half carcass were calculated.

\section{Statistical analyses}

Data were analysed by ANOVA using the General Linear Model procedure of the SPSS 10.0 program package (SPSS Inc., Chicago, IL, USA). Least-squares procedure was used in order 
to determine the effects of slaughter age and gender on carcass characteristics (Harvey 1987). The interaction between slaughter age and gender was not significant, therefore was excluded from the analysis. Differences were considered as significant when $P$-value was less than 0.05 . While comparing females and males, empty body weight was used as covariate for analysis of carcass measurements and non-carcass components; while left half carcass weight was used as covariate for analysis of carcass cuts. Using empty body weight and left half carcass weight as independent variables $(x)$, the relative growth coefficients for carcass measurements, non carcass components and carcass cuts $(y)$ were calculated from the equation of Huxley (1932)

$$
\log y=\log a+b \log x
$$

\section{Results and Discussion}

Slaughter weight, empty body weight, the percentages of non-carcass components and some carcass characteristics of Hair goat kids are presented in Table 1. The slaughter weight and empty body weight increased with slaughter age and the mean values of these traits in males were significantly higher than those of females $(P<0.001)$. The percentages of subproducts and visceral organs (based on slaughter weight) decreased when the slaughter age increased $(P<0.001)$. However, the percentages of full and empty gastro-intestinal tract of kids at 3 months of age were significantly lower than those of the other age groups. This result could be due to the development of the intestines and fat depots with rising slaughter age. Similar results were observed in previous studies (Marichal et al. 2003, Peña et al. 2007). Unlike the findings of this study, Bonvillani et al. (2010) reported that the contribution of visceral organs and fat depots as the percentages of empty body weight did not change with slaughter weight, while the percentage of stomach decreased in Criollo Cordobés kids slaughtered at 10-13.5 kg live weight. These differences between studies could be attributed to different breed and weight at slaughter. Gender did not have an effect on the percentages of non-carcass components, except for omental and mesenteric fat proportion, which was higher in females than in males $(P<0.001)$. This finding was similar to those recorded by Peña et al. (2007), Bonvillani et al. (2010) and Santos et al. (2007) for different goat breeds. Analysis of allometry coefficients of non-carcass components, in relation to empty body weight showed similar results. Allometric growth coefficients for the non-carcass components were lower than one, except for omental-mesenteric fat and empty gastro intestinal system in females. There were no significant differences between genders (Table 3).

Hot dressing percentage (based on empty body weight) of Hair goat kids slaughtered at 3-12 months of age ranged from $49.20 \%$ to $54.11 \%$. These values were within the range of reported values by (51.14\%) Koyuncu et al. (2007) for Hair goats in semi-intensive conditions and slaughtered at $21 \mathrm{~kg}$ live weight and the results (48-50\%) of Yilmaz et al. (2009) for Hair goat kids, Saanen $\times$ Hair goat $F_{1}$ and Saanen $\times$ Hair goat $B_{1}$ kids slaughtered approximately at 4 months of age under intensive management conditions. In the present study cold dressing percentage was in the range of 40-53\%. This results were similar to those recorded (41-53\%) by Marichal et al. (2003) for Canary Caprine Group genotype kids slaughtered at 6, 10, $25 \mathrm{~kg}$ body weight and (43-52\%) by Özcan et al. (2010) for Gokceada, Maltese and Turkish Saanen 
kids slaughtered at $11-16 \mathrm{~kg}$ body weight and (45\%) by Daskiran et al. (2006) for Norduz male kids slaughtered at $22 \mathrm{~kg}$ under pasture conditions. With an increase in slaughter age, a significant increase was observed in hot and cold carcass weights and dressing percentages $(P<0.001)$. This result was in accordance with the findings of Dhanda et al. (2003). On the other hand, Peña et al. (2007) and Peña et al. (2009) reported that there was no significant effect of slaughter weight on these traits. Significant differences between the genders were observed for hot and cold carcass weights $(P<0.001)$ and these traits were higher in male kids than female kids, whereas there was no significant effect of gender on hot and cold dressing percentages, being in agreement with the results of Peña et al. (2007) and Santos et al. (2007).

In this study, chilling loss significantly decreased with slaughter age $(P<0.01)$ (Table 1$)$, as previously reported by other researchers for different goat breeds (Peña et al. 2007, Bonvillani et al. 2010, Marichal et al. 2003). The lower chilling loss in the heavier kids could be due to the thicker subcutaneous fat of the carcass in heavier kids (Kirton 1988). Kid gender did not have a significantly influence on this trait $(P>0.05)$. Similarly, Santos et al. (2007) found that there wasn't any significant difference between genders in terms of this trait.

The percentage contribution of commercial joints obtained from left half of carcasses are shown in Table 2. The percentage contributions of shoulder (20.80-21.77\%), long leg (32.81$34.01 \%)$, ribs (23.07-24\%), flank (10.03-10.72\%) and tail (0.40-0.41\%) were not significantly affected by slaughter age. On the contrary, the percentages of neck (7.67-9.59\%) and kidney (0.83-1.00\%) decreased, while the percentage of kidney-knob and channel fat (1.05-1.41\%) increased as the slaughter age increased (allometric coefficients were 1.06 and 0.76 for females and males, respectively). These results, agree with those of Marichal et al. (2003) in Canary Caprine Group genotype male kids slaughtered at 6, 10, $25 \mathrm{~kg}$ live weights. Similarly, Peña et al. (2007) reported that the percentage of neck decreased, whereas the percentage of pelvic-renal fat increased with slaughter weight. On the other hand, Bonvillani et al. (2010) did not find any differences among slaughter weight groups. These differences among the studies may be due to slaughter weight and rearing conditions. There were no significant differences among genders in terms of primal cut percentages, whereas kidney-knob and channel fat significantly higher in females than those of males $(P<0.001)$. This finding was in accordance with the results of Peña et al. (2007) and Todaro et al. (2004).

Most of the fat is deposited in the visceral rather than carcass depots and hence goat carcasses are lean, with a low proportion of subcutaneous fat (Devendra \& Owen 1983, Kirton 1988). In the present study, the percentages of subcutan, intermuscular and total fat in the animals at 12 months of age were significantly higher than the other slaughter age groups $(P<0.01)$, whereas the percentage of bone of kids at 3 months of age was higher than those of the other slaughter age groups $(P<0.05)$ (Table 4$)$. Similarly, many researchers also reported that carcass fatness increased, whereas the percentage of bone decreased with slaughter weight of kids (Marichal et al. 2003, Zimerman et al. 2008, Dhanda et al. 2003, Peña et al. 2007). The higher fat content and the lower muscle content was obtained in the present study than those (5\% fat, 61-63\% muscle) recorded by Yilmaz et al. (2010) for Hair, Saanen $\times$ Hair Goat $F_{1}$ and Saanen $\times$ Hair Goat $B_{1}$ kids slaughtered at $17-18 \mathrm{~kg}$ under intensive rearing conditions. This might be because their analyses were performed on the leg, where fat depots were significantly lower than in whole carcass. On the other hand, Daskiran et al. (2010) found the lower muscle content ( $43.53 \%)$ and the higher fat content $(12.11 \%)$ for Norduz goats 
slaughtered at $30 \mathrm{~kg}$ live weight under extensive management conditions than our findings. The percentages of muscle and fat were lower; however the percentage of bone was higher in this study than those reported by Marichal et al. (2003) for Canary Caprine Group genotype kids slaughtered at 6, 10, $25 \mathrm{~kg}$ live weights, by Mahgoub et al. (2005) for Jebel Akhdar goat slaughtered at 11,18 and $28 \mathrm{~kg}$. This result could be explained with the difference of breed and rearing conditions.

The kid gender had significant influence on the percentage of subcutaneous, intermuscular and total fat, which was higher in females than males $(P<0.001)$. This result was in accordance with the findings of Peña et al. (2007). Similarly, Santos et al. (2007) found higher fat content in carcass of female kids than those of males, but the differences between genders were not significant.

Least-squares means of some carcass measurements of Hair goat kids are presented in Table 5. Carcass measurements and indices were significantly affected by the slaughter age $(P<0.001)$. The values of carcass and hind limb compactness indexes of kids at 3 months of age were significantly lower than those of the other slaughter age groups $(P<0.001)$ and also other investigated carcass measurements significantly increased with slaughter age $(P<0.001)$. Similar results were obtained in different studies. (Marichal et al. 2003, Peña et al. 2007, Zimerman et al. 2008, Bonvillani et al. 2010). The effect of gender on carcass measurements except for carcass compactness index and hind limb compactness index was statistically significant $(P<0.01, P<0.001)$. On the other hand, Peña et al. (2007) reported that kid gender only affected significantly $(P<0.05)$ internal carcass length, carcass compactness index and hind limb compactness index. However, Santos et al. (2007) found that the effect of gender on the carcass measurements was not statistically significant. Allometric growth coefficients of carcass measurements and indices were lower than one, which show early development of carcass measurements (Table 6). Similar patterns of growth coefficients of carcass measurements except for carcass compactness have been reported by Bonvillani et al. (2010). They obtained the higher growth coefficient for carcass compactness. This difference between these studies may be due to breed and rearing conditions.

In conclusion, the present study showed that increasing slaughter age from 3 to 12 months of age had positive effects on carcass characteristics, especially carcass weight, and dressing percentages. However, the kids slaughtered at the older age had the higher carcass and noncarcass fat deposition than those slaughtered at the younger ages. Hair goat kids slaughtered at 12 months of age had significantly higher muscle/total fat ratio than those the other age groups. Female kids slaughtered at the same age deposited more internal and carcass fat than male kids. It is recommended that Hair goat kids should be slaughtered at 9 months of age under extensive management system to result in more edible meat production.

\section{Acknowledgements}

This study was supported by Adnan Menderes University Research Fund (Project No: VTF08002). 
Table 1

Least-squares means $( \pm \mathrm{SE})$ of slaughter weight, empty body weight, the percentages of non-carcass components and some carcass characteristics in Hair goat kids Slaughter age, months

Gender

Effects

6

9

12

Female

Male

Slaughter Gender

Slaughter weight, kg

$15.36^{c} \pm 0.61$

$20.08^{b} \pm 0.58$

$21.60^{\mathrm{b}} \pm 0.60$

$24.57^{\mathrm{a}} \pm 0.71$

$18.44^{\mathrm{b}} \pm 0.45$

$22.36^{\mathrm{a}}+0.45$

Empty body weight, kg

$13.08^{c} \pm 0.59$

$16.76^{b} \pm 0.56$

$18.05^{\mathrm{b}} \pm 0.57$

$20.78^{a} \pm 0.69$

$15.43^{b} \pm 0.44$

$18.90^{\mathrm{a}} \pm 0.42$

Non-carcass components (as \% of slaughter weight)

\begin{tabular}{|c|c|c|c|c|c|c|c|c|}
\hline Subproducts & $19.27^{\mathrm{a}} \pm 0.41$ & $17.04^{b} \pm 0.41$ & $16.01^{b c} \pm 0.41$ & $14.84^{\mathrm{c}} \pm 0.47$ & $16.75 \pm 0.30$ & $16.83 \pm 0.30$ & $* * *$ & ns \\
\hline Visceral organs & $4.56^{a} \pm 0.11$ & $4.08^{b} \pm 0.11$ & $3.79^{b} \pm 0.11$ & $3.27^{c} \pm 0.13$ & $3.94 \pm 0.09$ & $3.91 \pm 0.09$ & $* * *$ & ns \\
\hline $\begin{array}{l}\text { Full gastro-intestinal } \\
\text { tract }\end{array}$ & $23.16^{b} \pm 0.63$ & $27.62^{\mathrm{a}} \pm 0.60$ & $27.11^{\mathrm{a}} \pm 0.63$ & $26.98^{a} \pm 0.73$ & $26.49 \pm 0.47$ & $25.94 \pm 0.47$ & $* * *$ & ns \\
\hline $\begin{array}{l}\text { Empty gastro-intestinal } \\
\text { tract }\end{array}$ & $8.29^{b} \pm 0.34$ & $10.88^{a} \pm 0.33$ & $10.42^{\mathrm{a}} \pm 0.35$ & $11.20^{\mathrm{a}} \pm 0.39$ & $10.23 \pm 0.25$ & $10.16 \pm 0.24$ & $* * *$ & ns \\
\hline $\begin{array}{l}\text { Omental and mesenteric } \\
\text { fat }\end{array}$ & $0.61^{c} \pm 0.03$ & $0.74^{b} \pm 0.03$ & $0.79^{b} \pm 0.03$ & $0.90^{\mathrm{a}} \pm 0.04$ & $0.92^{\mathrm{a}} \pm 0.02$ & $0.60^{b} \pm 0.02$ & $* * *$ & $* * *$ \\
\hline Hot carcass weight, kg & $6.43^{c} \pm 0.28$ & $8.84^{b} \pm 0.24$ & $9.37^{b} \pm 0.21$ & $11.13^{\mathrm{a}} \pm 0.33$ & $8.13^{b} \pm 0.21$ & $9.76^{\mathrm{a}} \pm 0.20$ & $* * *$ & $* * *$ \\
\hline Cold carcass weight, kg & $6.15^{c} \pm 0.31$ & $8.48^{\mathrm{b}} \pm 0.26$ & $9.11^{b} \pm 0.29$ & $10.83^{\mathrm{a}} \pm 0.33$ & $7.84^{b} \pm 0.21$ & $9.44^{\mathrm{a}} \pm 0.21$ & $* * *$ & $* * *$ \\
\hline $\begin{array}{l}\text { Hot dressing percentage, } \\
\%\end{array}$ & $49.20^{\complement} \pm 0.51$ & $52.81^{\mathrm{ab}} \pm 0.48$ & $52.06^{b} \pm 0.50$ & $54.11^{\mathrm{a}} \pm 0.59$ & $52.49 \pm 0.36$ & $51.60 \pm 0.38$ & $* * *$ & ns \\
\hline $\begin{array}{l}\text { Cold dressing } \\
\text { percentage, } \%\end{array}$ & $47.04^{c} \pm 0.49$ & $50.60^{b} \pm 0.46$ & $50.55^{b} \pm 0.48$ & $52.65^{a} \pm 0.57$ & $50.61 \pm 0.35$ & $49.81 \pm 0.36$ & $* * *$ & ns \\
\hline Chilling loss, \% & $4.41^{\mathrm{a}} \pm 0.34$ & $4.16^{\mathrm{a}} \pm 0.30$ & $2.90^{\mathrm{b}} \pm 0.33$ & $2.68^{b} \pm 0.39$ & $3.60 \pm 0.23$ & $3.47 \pm 0.25$ & $* *$ & ns \\
\hline
\end{tabular}

a,b,c Means within a row within slaughter age or gender class, followed by the different superscript are significantly different $(\mathrm{P}<0.05)$. ns: not significant; $* * P<0.01, \quad * * * P<0.001$. subproducts: skin + feet + head, visceral organs: lungs + trachea + heart + liver + spleen, hot dressing percentage: hot carcass weight/empty body weight, cold dressing percentage: cold carcass weight/empty body weight 
Table 2

Percentage contribution in relation to left half carcass weight of different carcass cuts (least-squares means \pm SE) of Hair goat kids

\begin{tabular}{|c|c|c|c|c|c|c|c|c|}
\hline \multirow[b]{2}{*}{ Characteristics } & \multicolumn{4}{|c|}{ Slaughter age, months } & \multicolumn{2}{|c|}{ Gender } & \multicolumn{2}{|c|}{ Effects } \\
\hline & 3 & 6 & 9 & 12 & Female & Male & $\begin{array}{l}\text { Slaughter } \\
\text { age }\end{array}$ & Gender \\
\hline Neck & $9.59^{\mathrm{a}} \pm 0.35$ & $8.14^{b} \pm 0.31$ & $7.98^{b} \pm 0.37$ & $7.67^{b} \pm 0.41$ & $8.17 \pm 0.24$ & $8.52 \pm 0.26$ & ** & ns \\
\hline Shoulder & $21.77 \pm 0.78$ & $21.65 \pm 0.74$ & $21.12 \pm 0.77$ & $20.80 \pm 0.90$ & $21.31 \pm 0.54$ & $21.36 \pm 0.58$ & ns & ns \\
\hline Long leg & $32.81 \pm 0.37$ & $33.50 \pm 0.33$ & $33.63 \pm 0.35$ & $34.01 \pm 0.40$ & $33.69 \pm 0.22$ & $33.28 \pm 0.25$ & ns & ns \\
\hline Ribs & $23.07 \pm 0.61$ & $23.54 \pm 0.65$ & $23.81 \pm 0.67$ & $24.00 \pm 0.75$ & $23.02 \pm 0.45$ & $24.18 \pm 0.48$ & ns & ns \\
\hline Flank & $10.03 \pm 0.35$ & $10.21 \pm 0.33$ & $10.64 \pm 0.36$ & $10.72 \pm 0.41$ & $10.06 \pm 0.26$ & $10.75 \pm 0.25$ & ns & ns \\
\hline Tail & $0.41 \pm 0.01$ & $0.40 \pm 0.02$ & $0.41 \pm 0.02$ & $0.40 \pm 0.03$ & $0.42 \pm 0.01$ & $0.39 \pm 0.02$ & ns & ns \\
\hline Kidney & $1.00^{\mathrm{a}} \pm 0.03$ & $0.95^{\mathrm{ab}} \pm 0.03$ & $0.88^{b c} \pm 0.02$ & $0.83^{c} \pm 0.04$ & $0.93 \pm 0.02$ & $0.90 \pm 0.02$ & ** & ns \\
\hline $\begin{array}{l}\text { Kidney-knob and } \\
\text { channel fat }\end{array}$ & $1.05^{c} \pm 0.06$ & $1.17^{b c} \pm 0.06$ & $1.24^{\mathrm{ab}} \pm 0.05$ & $1.41^{\mathrm{a}} \pm 0.07$ & $1.44^{\mathrm{a}} \pm 0.04$ & $0.99^{b} \pm 0.04$ & $* *$ & $* * *$ \\
\hline
\end{tabular}

a, b, cMeans within a row within slaughter age or gender class, followed by the different superscript are significantly different $(P<0.05)$. ns: not significant; ${ }^{* * P<0.01, ~}{ }^{* * *} P<0.001$ 
Table 3

Allometric growth coefficients of non-carcass components and carcass cuts, in relation to empty body weight and to half carcass weight, respectively

Non-carcass components (relative to empty body weight)

Subproducts

\section{Visceral organs}

Empty gastro-intestinal tract

Omental and mesenteric fat

Carcass cuts (relative to half-carcass weight)

Neck

Shoulder

Hind leg

Ribs

Flank

Kidney

Kidney-knob and channel fat
Females

$\mathrm{b} \pm \mathrm{SE}$

Males

$\mathrm{b} \pm \mathrm{SE}$

$r^{2}$

$\begin{array}{llll}0.58^{*} \pm 0.09 & 56.10 & 0.63^{*} \pm 0.07 & 74.60 \\ 0.48^{*} \pm 0.12 & 35.30 & 0.37^{*} \pm 0.06 & 53.90 \\ 1.08^{*} \pm 0.22 & 46.40 & 0.86^{*} \pm 0.18 & 43.60 \\ 1.06^{*} \pm 0.21 & 45.70 & 0.99 \pm 0.16 & 59.20\end{array}$

$0.64^{*} \pm 0.13 \quad 47.90 \quad 0.67^{*} \pm 0.09$

$0.67^{*} \pm 0.09$

$0.68 * \pm 0.08$

$0.99 \pm 0.03$

97.10

$1.01 \pm 0.03$

72.50

$0.88^{*} \pm 0.07$

84.90

$0.84^{*} \pm 0.07$

97.40

$1.11^{*} \pm 0.12$

75.60

$0.92^{*} \pm 0.08$

82.60

$0.58^{*} \pm 0.07$

69.70

$0.57^{*} \pm 0.08$

82.20

$1.06^{*} \pm 0.13$

58.70

$0.76^{*} \pm 0.17$

67.20

55.60

*indicates b value different from $1(P<0.05)$; subproducts: skin + feet + head, visceral organs: lungs + trachea + heart + liver + spleen, hot dressing percentage: hot carcass weight/ empty body weight, cold dressing percentage: cold carcass weight/empty body weight 
Table 4

Least-squares means ( \pm SE) of left half carcass composition (\%)

\begin{tabular}{|c|c|c|c|c|c|c|c|c|}
\hline & \multicolumn{4}{|c|}{ Slaughter age, months } & \multicolumn{2}{|c|}{ Gender } & \multicolumn{2}{|c|}{ Effects } \\
\hline & 3 & 6 & 9 & 12 & Female & Male & $\begin{array}{l}\text { Slaughter } \\
\text { age }\end{array}$ & Gender \\
\hline Muscle & $51.96 \pm 2.04$ & $53.91 \pm 2.01$ & $54.49 \pm 2.04$ & $55.80 \pm 2.35$ & $53.82 \pm 1.50$ & $54.26 \pm 1.51$ & ns & $\mathrm{ns}$ \\
\hline Bone & $39.00^{\mathrm{a}} \pm 1.44$ & $35.67^{\mathrm{ab}} \pm 1.41$ & $34.80^{\mathrm{b}} \pm 1.43$ & $31.93^{b} \pm 1.66$ & $35.63 \pm 1.04$ & $35.07 \pm 1.06$ & * & ns \\
\hline Subcutaneous fat & $3.51^{b} \pm 0.20$ & $3.76^{b} \pm 0.22$ & $3.98^{b} \pm 0.19$ & $4.77^{\mathrm{a}} \pm 0.23$ & $4.86^{a} \pm 0.15$ & $3.15^{b} \pm 0.11$ & $* *$ & $* * *$ \\
\hline Intermuscular fat & $3.94^{b} \pm 0.23$ & $4.39^{b} \pm 0.24$ & $4.46^{b} \pm 0.21$ & $5.31^{\mathrm{a}} \pm 0.27$ & $5.59^{\mathrm{a}} \pm 0.16$ & $3.46^{b} \pm 0.19$ & $* *$ & $* * *$ \\
\hline Total fat & $7.45^{b} \pm 0.42$ & $8.02^{b} \pm 0.40$ & $8.45^{b} \pm 0.41$ & $10.14^{\mathrm{a}} \pm 0.49$ & $10.39^{\mathrm{a}} \pm 0.31$ & $6.64^{b} \pm 0.30$ & $* *$ & $* * *$ \\
\hline Other tissues & $1.48 \pm 0.06$ & $1.53 \pm 0.03$ & $1.52 \pm 0.05$ & $1.53 \pm 0.07$ & $1.55 \pm 0.04$ & $1.47 \pm 0.04$ & ns & ns \\
\hline $\begin{array}{l}\text { Subcutan/ } \\
\text { intermuscular fat }\end{array}$ & $0.91 \pm 0.02$ & $0.91 \pm 0.01$ & $0.89 \pm 0.02$ & $0.88 \pm 0.03$ & $0.88 \pm 0.02$ & $0.91 \pm 0.01$ & ns & ns \\
\hline Muscle/total fat & $7.07^{a} \pm 0.19$ & $7.24^{\mathrm{a}} \pm 0.20$ & $6.93^{\mathrm{a}} \pm 0.17$ & $6.15^{b} \pm 0.22$ & $5.31^{b} \pm 0.14$ & $8.39^{\mathrm{a}} \pm 0.11$ & $* *$ & $* * *$ \\
\hline Muscle/bone & $1.33^{d} \pm 0.02$ & $1.51^{c} \pm 0.01$ & $1.58^{b} \pm 0.01$ & $1.75^{\mathrm{a}} \pm 0.02$ & $1.52 \pm 0.02$ & $1.56 \pm 0.01$ & $* * *$ & ns \\
\hline
\end{tabular}


Table 5

Least-squares means ( \pm SE) of some carcass measurements of Hair goat kids

Slaughter age, months

Effects

Carcass measurements

6

9

Gender

Effects

Internal carcass length, $\mathrm{cm}$

$49.22^{d} \pm 0.3$

$55.75^{c} \pm 0.30$

$58.56^{\mathrm{b}} \pm 0.30$

12

Female

Male

Slaughter Gender

Hind limb length, $\mathrm{cm}$

$26.52^{d}+0.36$

$29.89^{c} \pm 0.37$

$31.33^{b} \pm 0.36$

$63.83^{\mathrm{a}} \pm 0.35$

$56.22^{\mathrm{b}} \pm 0.22$

$57.47^{a} \pm 0.22$

Carcass width, $\mathrm{cm}$

$13.71^{\mathrm{c}} \pm 0.29$

$15.03^{b} \pm 0.31$

$15.58^{\mathrm{b}} \pm 0.30$

$34.67^{a} \pm 0.42$

$29.23^{b} \pm 0.27$

$31.98^{\mathrm{a}} \pm 0.28$

Buttock width, $\mathrm{cm}$

$11.37^{c} \pm 0.30$

$13.78^{\mathrm{b}} \pm 0.33$

$14.19^{b} \pm 0.31$

$16.72^{\mathrm{a}} \pm 0.34$

$14.82^{b} \pm 0.22$

$15.70^{\mathrm{a}} \pm 0.21$

$13.18^{\mathrm{b}} \pm 0.24$

$14.49^{\mathrm{a}} \pm 0.22$

Thorax perimeter, cm

$51.38^{d} \pm 0.76$

$56.90^{\complement} \pm 0.75$

$63.98^{\mathrm{b}} \pm 0.73$

$16.00^{\mathrm{a}} \pm 0.35$

$58.15^{\mathrm{b}} \pm 0.56$

$61.53^{\mathrm{a}} \pm 0.53$

$33.59^{c} \pm 0.78 \quad 39.62^{b} \pm 0.81$

$42.01^{\mathrm{a}} \pm 0.79$

$67.08^{\mathrm{a}} \pm 0.87$

$38.36^{\mathrm{b}} \pm 0.57$

$41.21^{\mathrm{a}} \pm 0.60$

Thorax depth, cm

$19.64^{d} \pm 0.37$

$22.28^{c} \pm 0.39$

$24.12^{\mathrm{b}} \pm 0.36$

$25.27^{\mathrm{a}} \pm 0.43$

$22.28^{\mathrm{b}} \pm 0.28$

$23.37^{a} \pm 0.25$

$125.02^{\mathrm{b}} \pm 6.08$

$152.21^{\mathrm{a}} \pm 6.08$

$155.43^{\mathrm{a}} \pm 6.11$

$169.27^{\mathrm{a}} \pm 7.02$

$146.39^{\mathrm{a}} \pm 4.47$

$154.57^{\mathrm{a}} \pm 4.49$

$38.04^{\mathrm{b}} \pm 1.99 \quad 48.82^{\mathrm{a}} \pm 1.99 \quad 47.53^{\mathrm{a}} \pm 1.98 \quad 51.53^{\mathrm{a}} \pm 2.29 \quad 47.49^{\mathrm{a}} \pm 1.46 \quad 45.46^{\mathrm{a}} \pm 1.46$

$38.04^{\mathrm{b}} \pm 1.99 \quad 48.82^{\mathrm{a}} \pm 1.99 \quad 47.53^{\mathrm{a}} \pm 1.98 \quad 51.53^{\mathrm{a}} \pm 2.29 \quad 47.49^{\mathrm{a}} \pm 1.46 \quad 45.46^{\mathrm{a}} \pm 1.46$

$* * *$

ns

Hind limb compactness

index, $\mathrm{g} / \mathrm{cm}$

a,b,c,dLeast square means on the same row within slaughter age or gender class, followed by the different letter are significantly different $(P<0.05) . \quad$ ns: not significant, $* * P<0.01$, $* * * P<0.001$ 
Table 6

Allometric growth coefficients, in relation to empty body weight, of the measurements and indices determined in the carcasses of Hair goat kids

\begin{tabular}{|c|c|c|c|c|}
\hline \multirow[b]{2}{*}{ Carcass measurements } & \multicolumn{2}{|c|}{ Females } & \multicolumn{2}{|c|}{ Males } \\
\hline & $\mathrm{b} \pm \mathrm{SE}$ & $r^{2}$ & $\mathrm{~b} \pm \mathrm{SE}$ & $r^{2}$ \\
\hline Internal carcass length, $\mathrm{cm}$ & $0.32 * \pm 0.06$ & 47.70 & $0.34^{*} \pm 0.05$ & 66.10 \\
\hline Hind limb length, $\mathrm{cm}$ & $0.39 * \pm 0.09$ & 38.60 & $0.26^{*} \pm 0.05$ & 46.90 \\
\hline Carcass width, cm & $0.32^{*} \pm 0.08$ & 39.20 & $0.28^{*} \pm 0.06$ & 45.30 \\
\hline Buttock width, cm & $0.46^{*} \pm 0.10$ & 41.30 & $0.48^{*} \pm 0.08$ & 59.50 \\
\hline Thorax perimeter, $\mathrm{cm}$ & $0.40^{*} \pm 0.07$ & 52.90 & $0.36^{*} \pm 0.06$ & 52.50 \\
\hline Buttock perimeter, $\mathrm{cm}$ & $0.49^{*} \pm 0.07$ & 61.90 & $0.46^{*} \pm 0.07$ & 62.60 \\
\hline Thorax depth, cm & $0.41^{*} \pm 0.08$ & 48.50 & $0.32^{*} \pm 0.06$ & 47.20 \\
\hline Carcass compactness index, $\mathrm{g} / \mathrm{cm}$ & $0.46^{*} \pm 0.16$ & 22.70 & $0.45^{*} \pm 0.13$ & 29.50 \\
\hline Hind limb compactness index, $\mathrm{g} / \mathrm{cm}$ & $0.40^{*} \pm 0.17$ & 16.80 & $0.50^{*} \pm 0.14$ & 30.80 \\
\hline
\end{tabular}

*indicates b value different from $1(P<0.05)$ 


\section{References}

Anonymous (2009) Animal Production Statistics, 2009. Press Release No. 87, Turkish Statistical Institute, Turkey, http://www.turkstat.gov.tr/PreHaberBultenleri.do?id=6250 [last accessed 01.09.2013]

Bonvillani A, Peña F, de Gea G, Gómez G, Petryna A, Perea J (2010) Carcass characteristics of Criollo Cordobés kid goats under an extensive management system: Effects of gender and liveweight at slaughter. Meat $\mathrm{Sci}$ $86,651-659$

Colomer-Rocher F, Morand-Fehr P, Kirton AH (1987) Standard methods and procedures for goat carcass evaluation, jointing and tissue separation. Livestock Prod Sci 17, 149-159

Colomer-Rocher F, Kirton AH, Mercer GJK, Duganzich DM (1992) Carcass composition of New Zealand Saanen goats slaughtered at different weights. Small Rumin Res 7, 161-173

Dhanda JS, Taylor DG, Murray PJ (2003) Part 1. Growth, carcass and meat quality parameters of male goats: effects of genotype and liveweight at slaughter. Small Rumin Res 50, 57-66

Daskiran I, Kor A, Bingol M (2006) Slaughter and carcass characteristics of Norduz male kids raised in either intensive or pasture conditions. Pak J Nutr 5, 274-277

Daskiran I, Bingol M, Karaca S, Yilmaz A, Cetin AO, Kor A (2010) The effect of feeding system on fattening performance, slaughter, and carcass characteristics of Norduz male kids. Trop Anim Health Prod 42, 14591463

Devendra C, Owen JE (1983) Quantitative and qualitative aspects of meat production from goats. World Anim $\operatorname{Rev} 47,19-29$

Fisher AV, de Boer H (1994) The EAAP Standard method of sheep carcass assessment. Carcass measurements and dissection procedures report of the EAAP working group on carcass evaluation, in cooperation with the CIHEAM instituto ggronomico Mediterraneo of Zaragoza and the CEC directorate general for agriculture in Brussels. Livestock Prod Sci 38, 149-159

Guney 0 (2006) [Meat production in goats]. In: Kaymakçı M (ed) [Goat breeding]. İzmir illi Damızlık Koyun-Keçi Yetiştiricileri Birliği Yayınları, Bornova, Izmir, Türkiye, 93-114 [in Turkish]

Gürsoy O, Sentut T, Cankaya S (2011) Feedlot performance and carcass characteristics of Kilis goat breed. Maced J Anim Sci 1, 39-51

Harvey WR (1987) User's guide for LSMLMWPC-1 version mixed model least squares and maximum likelihood computer program, Ohio State Univ., Columbus, Mimeo, USA

Huxley JS (1932) Problems of relative growth. Dial Press, New York, USA

Kirton AH (1988) Characteristics of goat meat including carcass quality and methods of slaughter. In: Goat Meat Production in Asia. Proceedings of the International Workshop on Goat Meat Production in Asia, Tando Jam (Pakistan), 12-18 Mar 1988, Sind Agriculture University, International Development Research Center (IDRC), Ottawa, Canada, 87-99

Koyuncu M, Duru S, Kara Uzun S, Özis S, Tuncel E (2007) Effect of castration on growth and carcass traits in hair goat kids under a semi-intensive system in the South-Marmara Region of Turkey. Small Rumin Res 72, 38-44

Mahgoub O, Kadim IT, Al-Saqry NM, AI-Busaidi RM (2005) Potential of Omani Jebel Akhdar goat for meat production under feedlot conditions. Small Rumin Res 56, 223-230

Marichal A, Castro N, Capote J, Zamorano MJ, Argüello A (2003) Effects of live weight at slaughter (6, 10 and $25 \mathrm{~kg}$ ) on kid carcass and meat quality. Livestock Prod Sci 83, 247-256

Özcan M, Yilmaz A, Ekiz B, Tölü C, Savas T (2010) Slaughter and carcass characteristics of Gokceada, Maltese and Turkish Saanen suckling kids. Arch Tierz 53, 318-327

Peña F, Perea J, García A, Acero R (2007) Effects of weight at slaughter and sex on the carcass characteristics of Florida suckling kids. Meat Sci 75, 543-550

Peña F, Bonvillani A, Freire B, Juárez M, Perea J, Gómez G (2009) Effects of genotype and slaughter weight on the meat quality of Criollo Cordobes and Anglonubian kids produced under extensive feeding conditions. Meat Sci 83, 417-422 
Potchoiba MJ, Lu CD, Pinkerton F, Sahlu T (1990) Effects of all-milk diet on weight gain, organ development, carcass characteristics and tissue composition, including fatty acids and cholesterol content, of growing male goats. Small Rumin Res 3, 583-592

Santos VAC, Silva AO, Cardoso JVF, Silvestre AJD, Silva SR, Martins C, Azevedo JMT (2007) Genotype and sex effects on carcass and meat quality of suckling kids protected by the PGI „Cabrito de Barroso«. Meat Sci $75,725-736$

Todaro M, Corrao A, Alicata ML, Schinelli R, Giaccone P, Priolo A (2004) Effects of litter size and sex on meat quality traits of kid meat. Small Rumin Res 54, 191-196

Yalcin BC (1990) [Goat breeding]. In: Aytug CN, Alacam E, Ozkoç U, Yalcin BC, Gokcen H, Turker H (eds). [SheepGoat Diseases and Breeding], TÜM VET Hayvancllık Hizmetleri Yayını, Istanbul, Türkiye, 450-468 [in Turkish]

Yilmaz A, Ekiz B, Ozcan M, Kaptan C, Hanoglu H, Yildirir M (2009) Effects of crossbreeding indigenous Hair Goat with Saanen on carcass measurements and meat quality of kids under an intensive production system. Anim Sci J 80, 460-467

Yilmaz A, Ekiz B, Ozcan M, Kaptan C, Hanoglu H, Yildirir M, Kocak O (2010) Carcass quality characteristics of Hair Goat and Saanen x Hair Goat crossbred kids from intensive production system. J Anim Feed Sci 19, 368-378

Zimerman M, Domingo E, Lanari MR (2008) Carcass characteristics of Neuquén Criollo kids in Patagonia region, Argentina. Meat Sci 79, 453-457 